\title{
Understanding the Footprint of the RBV in International Business Studies: the Last Twenty Years of Research
}

\author{
Manuel Aníbal Silva Portugal Vasconcelos Ferreira ${ }^{\dagger}$ \\ Universidade Nove de Julho \\ Instituto Politécnico de Leiria \\ Nuno Rosa Reis ${ }^{\Omega}$ \\ Instituto Politécnico de Leiria \\ Fernando A. Ribeiro Serra ${ }^{¥}$ \\ Universidade Nove de Julho \\ Benny Kramer Costa \\ Universidade Nove de Julho
}

\begin{abstract}
International business (IB) research has evolved substantially over the past four decades incorporating new concerns and theoretical contributions. During the past two decades, the Resource-Based View (RBV) has gained the preference of many IB scholars and has gradually become one of the dominant theoretical perspectives for studying IB decisions and operations. The 1991 article "Firm resources and sustained competitive advantage" by Jay Barney is recognized as a fundamental contribution to the Resource-Based View (RBV). In this paper we assess the influence of the RBV, proxied by Jay Barney's (1991) article, on IB research over the twenty years period, from 1991 to 2010. In this bibliometric study of the articles published in the leading journal for IB research - Journal of International Business Studies (JIBS) - we conduct citation and co-citation analyses, the networks of co-authorship, and delve into the analysis of the key research topics. Beyond understanding the extant research we also contribute to identifying future research avenues.
\end{abstract}

Keywords: RBV. Review. Bibliometric study. International business research. Research perspectives.

Recebido em 29/06/2012; revisado em 30/01/2013; aceito em 11/06/2013; divulgado em 29/08/2014

*Autor para correspondência:

${ }^{\dagger}$. Doutor pela David Eccles School of Business da Universidade de Utah, EUA

${ }^{\Omega}$ Doutorando na Faculdade de Economia da Universidade de Coimbra, Portugal

Vínculo: Escola Universidade Nove de Julho e Instituto Politécnico de Leiria Endereço: Av. Francisco Matarazzo, São Paulo - SP - Brazil

E-mail:

manuel.portugal.ferreira@gmail.com Telefone: (11) 960224462
Superior de Tecnologia

e Gestão, Instituto

Politécnico de Leiria,

Portugal

Endereço: Morro do

Lena Leiria, Portugal.

E-mail:

nuno.m.reis@ipleiria.pt
${ }^{¥}$ Doutor em Engenharia pelo DCMM da Pontifícia Universidade Católica do Rio de Janeiro - PUC-Rio Vínculo:Professor Titular da Universidade Nove de Julho Endereço: Av. Francisco Matarazzo, São Paulo - SP Brazil - E-mail:

fernandoars@uninove.br Telefone: (21) 98230-0781
† Doutor em Administração pela Faculdade de Economia, Administração e Contabilidade da Universidade de São Paulo Vínculo:Professor Titular da Universidade Nove de Julho Endereço: Av. Francisco Matarazzo, São Paulo - SP Brazil - E-mail: bennycosta@yahoo.com.br Telefone: ( 11 ) 991585040 


\section{INTRODUCTION}

he international business (IB) research has received multiple influences from other areas of knowledge ranging from sociology (SINKOVICS; PENZ, 2009) to economics (BEAUDRY; DUPAIGNE; PORTIER, 2011), entrepreneurship (JONES; COVIELLO; TANG, 2011), and strategic management (LU, 2003; DOH, 2005; VAPOLA; PAUKKU; GABRIELSSON, 2010; BRANNEN; DOZ, 2010), among others. As the discipline evolves towards taking the multinational firm as one of the main unit of analyses, so does grow the importance of strategic management concepts to IB scholars. Using theoretical insights grounded on strategic management research, IB scholars attempt to comprehend how multinational firms obtain a competitive advantage by delving into questions such as the selection of entry modes and of foreign markets, whether to internalize or outsource manufacturing or other activities, to internationalize gradually or start-up immediately with a global mindset and planning worldwide operations, and so forth. One of the frameworks proposed by strategic management research that has gained wide acceptance by IB scholars is the Resource-Based View (RBV).

The RBV and variants such as the knowledge-based view or the capabilities-based perspectives have been used to investigate IB topics (PENG, 2001; PITELIS, 2004). Specifically, over the past two decades, IB research has drawn from strategic management the quest to understand how may firms, and multinational firms, gain a sustainable competitive advantage and outperform others. In IB research a complete answer might entail scrutinizing a diverse pool of challenges that multinationals encounter when internationalizing their operations to foreign countries (BUCKLEY; PASS; PRESCOTT, 1992; MCDOUGALL; SHANE; OVIATT, 1994; BUCKLEY; CHAPMAN, 1996; CHANDRA; NEWBURRY, 1997; LEONIDOU; KATSIKEAS; COUDOUNARIS, 2010). Research has thus focused on such decisions as the entry modes into foreign markets, the selection of the host countries, whether to expand abroad manufacturing in the host locations or rather outsourcing to a local firm, among many others sets of decisions.

The RBV has been employed by IB scholars to assess differences between firms and better understand how firms actually compete, and it has rapidly gained the status of a core theoretical approach (RAMOS-RODRIGUEZ; RUIZ-NAVARRO, 2004). It is possible to identify RBV's origins to seminal works by Penrose (1959), Wernerfelt (1984) and Dierickx and Cool (1989). But the RBV has gained scholars attention from the 1990's, specifically 
after Jay Barney's (1991) crucial article "Firm resources and sustained competitive advantage", where Barney advances the indispensable traits (the VRIN acronym that stands for valuable, rare, inimitable and non-substitutable) firms' resources must hold to create a competitive advantage. Barney's (1991) paper has had a deep impact on the discussion surrounding RBV, recognized both by advocates and antagonists of the RBV. After Barney's article, the RBV has evolved to become one of the most used theoretical frameworks in many fields of business research, including IB (PENG, 2001; NEWBERT, 2007; KRAAIJENBRINK; SPENDER; GROEN, 2010; ROUSE; DAELLENBACH, 2010). The RBV's core proposition has also been shared by related, or variant, streams of thought such as the core competences (HAMEL; PRAHALAD, 1994), dynamic capabilities (NELSON; WINTER, 1982; TEECE; PISANO; SHUEN, 1997; HELFAT; PETERAF, 2003) and the knowledge-based view (KOGUT; ZANDER, 1992; GRANT, 1996). In fact, the RBV came to complement the industrial organization view (IO) (BAIN, 1968; PORTER, 1979, 1980) shifting the focus of firm performance from the structure-conduct-performance paradigm and the emphasis on the industry's structure, to start looking inside the firm and searching for firms' sources of competitive advantage to explain why firms in the same industry could have performance differences (MAHONEY; PANDIAN, 1992; BARNEY, 2002; PETERAF; BARNEY, 2003). In this paper we review the extent to which has the RBV - which we proxy using Barney's (1991) article - been included on IB research, the authors and research themes studied. We conduct a bibliometric study in the highest status journal for IB research (PHENE; GUISINGER, 1998) - Journal of International Business Studies (JIBS) - to observe trends, identify impact and connections binding authors, theories and issues addressed in the extant research, and detect possible gaps. Our bibliometric study comprises all articles published in JIBS from 1991 to 2010, and entails three procedures: citation and cocitation analyses, networks of authorship and research themes.

This paper is organized in four main sections. First, we review the RBV framework and Jay Barney's work on RBV. Second, we present the methodology used and explain the procedures and sample. The third section comprises the results of the analyses. We conclude with a broad discussion, limitations and future directions for research.

\section{LITERATURE REVIEW}

The RBV framework focuses on firms' resources and capabilities to explain their competitive advantage. Unlike earlier perspectives which explained competitive advantage based on the firms' position in an industry (PORTER, 1980) or based on the minimization of 
transaction costs (WILLIAMSON, 1975), the RBV looks inside firms to determine the sources of competitive advantage (BARNEY, 1991). Thus, RBV emerges as a complementary perspective to the $\mathrm{IO}$ view and to the transaction costs perspectives to overcome the limitations of only observing either the industry's structure or the transactions among firms, by placing a strong emphasis on firms' heterogeneous and idiosyncratic resources. Scholars use RBV to understand the heterogeneity of resources and how firms' resources affect the way firms compete. RBV's emphasis on the characteristics of the firms' resources, and on how firms acquire and organize internally their resources became a central point in much of the future research.

The RBV finds its origins in the 1980's with multiple contributions of scholars such as Penrose (1959), Wernerfelt (1984), Rumelt (1984), Barney (1986; 1991), Dierickx and Cool (1989), Peteraf (1993), Kogut and Zander (1992, 1993), Amit and Schoemaker (1993), Teece et al. (1997), Helfat and Lieberman (2002), among others. Since then, the RBV has been applied to a wide range of phenomena and used in several disciplines, including strategic management (OLIVER, 1997), entrepreneurship (JONES; COVIELLO: TANG, 2011) and international business (PENG, 2001). An extensive review is beyond the scope of our paper, since it is commonly held knowledge, but we briefly present an overview of RBV and of its use in IB research. A thorough review may be found in a number of studies such as Peng (2001), Lockett, Thompson and Morgenstern (2009) and Newbert (2007). The RBV focus on the use and the pooling of firms' resources to maximize the value of the firm (DAS: TENG, 2000). The assumption supporting RBV is that firms are bundles of idiosyncratic resources and thus obtain different outcomes, even when operating in the same industry (SHARMA; ERRAMILLI, 2004). On the other hand, some resources are not transferable - either because they are hard to copy or scarce - preventing rival firms from mimicking the bundle of resources. Therefore, the RBV explains a firm's sustainable competitive advantage based on the heterogeneous bundle of resources that cannot be, at least easily, transferred or copied by others.

Jay Barney's role in the development of RBV is arguably undisputed. His 1991 article 'Firm resources and sustained competitive advantage' put forward the VRIN framework, standing for valuable, rare, inimitable and non-substitutable, which seeks to explain the key factors underlying how firms might create and maintain a competitive advantage. Barney's VRIN framework plays a crucial role in all RBV rationale, as it sets the conditions in which a sustainable competitive advantage is achieved. Barney (1991) thus integrate concepts such as 
core competences (HAMEL: PRAHALAD, 1994), dynamic capabilities (TEECE; PISANO: SHUEN, 1997), competencies (PRAHALAD; HAMEL, 1990), strategic assets (AMIT; SCHOEMAKER, 1993) and others to explain a firm's competitive advantage based upon the resources the firm holds and the way in which it uses them. The RBV has been used by many IB scholars to address different subjects. For instance, to research multinationals' growth strategies and existence, the choices regarding subsidiaries (BIRKINSHAW; HOOD, 1998), the entry modes chosen (SHARMA; ERRAMILLI, 2004), the decision to explore new resources or exploit existing resources abroad (FERREIRA, 2008) and so forth. Other scholars have focused on how firms develop specific advantages based on their pool of resources that allow them to overcome the difficulties of operating abroad (BARTLETT; GHOSHAL, 1989; TALLMAN, 1991; KOSTOVA; ZAHEER, 1999). Yet other scholars have examined how the multinational corporations (MNCs) are able to transfer the knowledge internally and use their subsidiaries to learn and develop new capabilities that may be exploited in other locations and other businesses (BIRKINSHAW; HOOD, 1998; GUPTA; GOVINDARAJAN, 2000; FERREIRA, 2005). However RBV still needs to answer how the MNC may combine the capabilities spread across the subsidiaries into a single corporate-level competence (FERREIRA, 2008).

The RBV has also been used on the study of firms' entry modes into foreign markets (SHARMA; ERRAMILLI, 2004). Traditionally IB research emphasized a transaction cost approach and the impact of transaction costs on the choice of entry modes, to select the mode that minimized these costs (ANDERSON; GATIGNON, 1986; FERREIRA; SERRA, 2010). The transaction costs a firm faces are related to market failures such as information asymmetries, asset specificity and tacitness of knowledge (WILLIAMSON, 1985). Thus firms would choose the entry strategy which allowed them to overcome the market failures at the lowest cost. Current research however has a greater emphasis on explaining the entry mode choice based on how the resources and capabilities may be leveraged and increased abroad (CHANG, 1995; KOGUT, 1997; VERMEULEN; BARKEMA, 2001). The focus has thus been on how MNCs may prefer an entry mode over other because it allows increasing its capabilities (FERREIRA, 2005, 2008) not simply because it is the best mode to exploit already held capabilities.

Other stream of IB research deals with different forms of partnerships, from international strategic alliances and joint ventures to firms' networks. Using an RBV approach scholars argue that firms engage in partnerships whenever they can improve performance by 
learning from the partner and from the host countries (GULATI; LAVIE; SINGH, 2009). One concern is, for instance, considering the resources of the prospective partner: the driving force of choosing a partnership may be the resources and capabilities of the foreign firm and not the firm-specific advantages already held (TALLMAN; FLADMOE-LINDQUIST, 2002; FERREIRA, 2005).

RBV has also been used in studying product and geographic diversification (TALLMAN; LI, 1996; GERINGER; TALLMAN; OLSEN, 2000), namely to emerging countries (MEYER, 2001; GELBUDA; MEYER; DELIOS, 2008) in combination with institutional theory. RBV focus on which are the context-specific resources and competences a firm should hold and use abroad to achieve sustainable competitive advantage (MEYER; PENG, 2005), including the ability to deal with the institutional environments encountered and the foreign entry modes selected (UHLENBRUCK; DE CASTRO, 2000; FERREIRA; LI; JANG, 2009). For instance, the RBV posits that in emerging countries weak legal institutions may be overcome by using networks with suppliers and clients (MEYER et al., 2009). On the other hand, holding context-specific capabilities such as organizational flexibility may lead to competitive advantage in emerging countries (MEYER et al., 2009). This perspective is at least in part contrary to the transaction costs theory which focuses primarily on the characteristics of the resources a firm should transfer to its operations abroad (HENNART, 1982).

\section{METHOD}

In this paper we carry out a bibliometric study of all the papers published in the leading journal for publishing IB research - the Journal of International Business Studies (JIBS) (PHENE; GUISINGER, 1998; DUBOIS; REEB, 2001). The bibliometric study of the papers published during 1991 to 2010 permits us assessing the extent to which the RBV has been used in IB research. Specifically, we use Barney's (1991) paper as a proxy to examine the RBV. Moreover, we restricted our analyses to the citations, co-citations, co-authorships and research issues to make sense of the extant research. Methodologically, for the citations and co-citations analyses, we followed the approach suggested by Ramos-Rodriguez and RuizNavarro (2004), while to examine the research issues scholars have studied we followed the procedure in Furrer, Thomas and Goussevskaia (2008).

Bibliometric studies use published data - usually documental sources such as articles, books, dissertations, company reports, and other printed documents - to uncover relations between authors, subjects, theories, references and so forth (DIODATO, 1994). We only 
examined the articles published in one journal, mainly because the articles published in scholarly outlets already overcame the reviewing process and are considered certified knowledge. On the other hand, it is likely that leading journals also publish leading research on the field.

Bibliometric studies entail a review of the literature and have been carried out in several other disciplines and with different purposes. Phelan, Ferreira and Salvador (2002) examined authorship, length, types of articles and time lag for publication. Ramos-Rodriguez and RuizNavarro (2004) used the SMJ archive to detect the intellectual ties on strategic management research. Ferreira (2011) assessed the influence of a single scholar in the discipline using similar methods.

\subsection{SAMPLE}

To conduct our bibliometric study, we collected the data from the ISI Web of knowledge website (available in isiknowledge.com). We selected the publication - JIBS - and searched the 921 articles published in JIBS from 1991 to 2010 for those that cited Barney (1991). We identified 77 articles for further analyses. We retrieved all the relevant information for the analyses such as authors, author-supplied keywords and reference list. The data was retrieved and organized using the software bibexcel. The visual representations of the networks were drawn with Ucinet. The initial year for analyses was 1991 because this was the year Jay Barney published "Firm resources and sustained competitive advantage". Arguably, we should point out at the outset that there were certainly other papers on the RBV and arguably even with a larger theoretical contribution - we could point out, for instance, the works by Penrose (1959), Peteraf (1993), Wernerfelt (1984) and even works in variants of the RBV such as the dynamic capabilities (e.g., TEECE, PISANO; SHUEN, 1997) or the knowledgebased view (e.g., GRANT, 1996) - but it is reasonable to use Barney (1991) given its large number of citations - it is one of the most cited pieces on the RBV and a "compulsory" reference in any paper that truly deals with the RBV.

Barney's (1991) work has been regarded as the "first formalization of the thenfragmented resource-based literature into a comprehensive (and thus empirically testable) theoretical framework" (NEWBERT, 2007, p. 123). Barney's arguments drew from extant works by Penrose (1959), Rumelt (1984), Wernerfelt (1984), Dierickx and Cool (1989), among others to build two assumptions that have largely become core to the RBV: resources are heterogeneously distributed across firms, and are imperfectly mobile. The salience of Barney's (1991) work as a proxy for the RBV has also been used by Peng's (2001) work on 
the resource-based view in IB research. In fact, Peng selected two seminal pieces on the RBV - Barney (1991) and Wernerfelt (1984) - to identify those papers on IB that used an RBV lens, by observing citations to these two seminal works. These papers were selected for acknowledged influence (WERNERFELT, 1995; PRIEM; BUTLER, 2001).

Acedo, Barroso and Galan (2006) examining, employing bibliometric techniques, how the RBV had disseminated across management and the main trends, distinguished three streams of research within the resource-based theory: the RBV, the knowledge-based view and the relational view, and noted that Barney's (1991) was among the top references for the RBV, along with Wernerfelt's (1984) work. In Acedo et al. (2006) citation data was used as a measure of relevance, such that most cited works are taken as more influential. In fact, in Acedo et al. (2001) the scholars used Barney (1991) as the key marker for the RBV and only in Acedo, Barroso, Casillas and Galan (2001) did they extend to include additional journals and additional authors, specifically Wernerfelt (1984), thus extending the time frame of their analysis from 1992 to 1984.

\subsection{PROCEDURES PERFORMED}

The bibliometric study comprised three different and complementary procedures using the data from the 77 articles in our sample: a citation and co-citation analysis, a co-authorship analysis to uncover the networks of authors citing Barney (1991), and a keyword analysis to scrutinize the themes dealt with in the articles of our sample. The procedures are explained.

A citation analysis assumes that authors cite other scholars' work whenever it is relevant to their own work, to legitimize their work in a given discipline or topic, or even as a signal that positions a paper within a certain theory or stream of research. Therefore, it is reasonable to state that the most cited works are the most important or influential in the field of knowledge (RAMOS-RODRIGUEZ; RUIZ-NAVARRO, 2004). Using the list of bibliographical references, we are able to identify the frequency with which a given work is used - and count citations. Nonetheless, simply observing citations does not permit identifying the specific context in which they are made and in fact, scholars may cite other works to support an argument, to contrast with an alternative perspective or to criticize the work.

A co-citation analysis uses the list of references to identify similarities and connections between articles. We proxy the similarities by analyzing which works are jointly cited in different papers (see also WHITE; MCCAIN, 1998; RAMOS-RODRIGUEZ; RUIZNAVARRO, 2004) and we assume that two works have a greater connection when they are 
co-cited more often. We performed a co-authorship analysis to analyze the networks of authors who cited Barney's (1991) article. Co-authorship offers a different perspective of the intellectual structure of authors who use Barney’s (1991) article.

The third procedure involved identifying the themes of the articles. Arguably the common procedure to identify what a paper is about involves reading it or doing some form of content analysis. We resorted to a different procedure that entailed analyzing the authorsupplied keywords of each article that cited Barney (1991). We followed the procedure put forth by Furrer, Thomas and Goussevskaia (2008) and grouped the author-supplied keywords into major themes. The grouping was carried out by two coders who jointly decided how to classify each keyword into one of the major 21 themes (see appendix). Some adjustments were made to Furrer et al.'s listing to accommodate the specificity of IB-related research themes issues - we included the following themes: 'Multinational enterprise and subsidiaries', 'Foreign direct investment' and 'Environmental, geography, clusters and regional'. This analysis used the keywords from 52 articles (213 keywords) because JIBS did not include author-supplied keywords on the articles published prior to 2003. It is worth noting that using author-supplied keywords is a reasonable, albeit hardly perfect, to assess content since authors select keywords for their articles with the purpose of identifying the paper and for indexing purposes - we thus assume that the author-supplied keywords provide a reasonable proxy for the article content.

\section{RESULTS AND ANALYSES}

In Figure 1 we depict the co-citation map of the forty most cited references in the 77 articles selected for citing Barney's paper. In total, the 77 papers used 4,355 references. A cocitation map presents three core phenomena: the ties connecting the different works, the strength of those ties and the relative position of a work in the network. The figure may be read as follows: the thicker the line connecting a pair of works the stronger the connection between them, i.e., the more often they are jointly cited. Concerning the relative position in the network, the closer to the center of the network the more important, or central, is a given work. The works in central positions are cited more often than the works in the outer layer. Albeit important, the works in the outer layer are slightly less relevant to the other works in the network, such as Scott (1995) book on organization theory, Vernon (1966) on the international product life cycle, North (1990) on the institutional theory, Williamson (1975) and Coase (1937) on the transaction costs, and so forth. 
In our paper, Barney (1991) appears in the central position given it is the focus of the study, but other works appear close to the center, such as Wernerfelt (1984), Penrose (1959), Buckley and Casson (1976) and Johanson and Vahlne (1977). All these works are shown as closely related to Barney (1991). That does not signify that they are conceptually alike but rather that they are used jointly on IB research. For instance, a scholar examining the internationalization of firms may cite Johanson and Vahlne and also examine how internationalization may be influenced by resource-based motivations, thus citing Barney's work. Therefore, combining the relative position in the network and the strength of the ties we assess the use of the works (articles and books) by researchers.

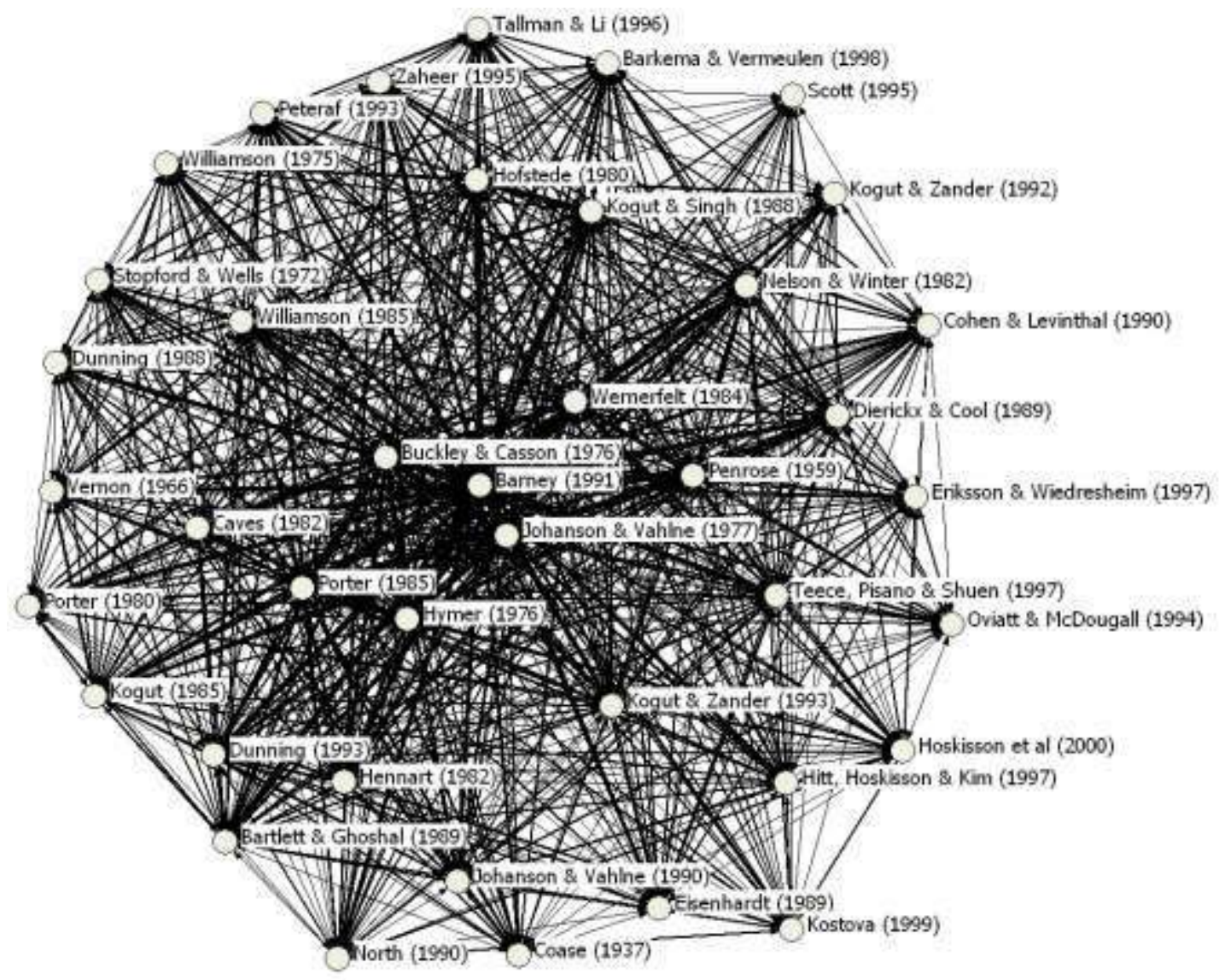

Figure 1 - Co-citation map of the 40 most cited works

Source: All works identified cited Barney's (1991) article. Data retrieved from ISI Web of Knowledge. Authors' computations using Bibexcel. Drawn with Ucinet.

We observed possible shifts in the citation counts to determine any changes on the IB research focus. The procedure entailed setting two periods - 1991-2000 and 2001-2010 - and assess which works were the most cited in each period (see Table 1). On the table we see the citations of each work and its relative impact measured as a percentage of the total citations of papers published in JIBS (column \%). It becomes rather visible the increase of the RBVrelated research from the first to the second period - while in the first period Barney's (1991) 
paper was cited by $3.76 \%$ of all articles, in the second period it was cited by $10.65 \%$. This shift may not be surprising to some IB scholars and actually reflects a shift from more country and industry factors or even a transaction costs approach (KINDLEBERGER, 1969; HYMER, 1976; CAVES, 1982; PORTER, 1985, 1986; WILLIAMSON, 1985) to the firm with an emphasis on knowledge, resources and capabilities (KOGUT; SINGH, 1988; KOGUT; ZANDER, 1993; TEECE; PISANO; SHUEN, 1997). Additionally, this shift accompanies a growing trend of IB moving towards international strategy and becoming a more business/management discipline and less economics (PENG, 2001).

Table 1 - Ranking of Most Cited Authors in Papers Published in JIBS

\begin{tabular}{|c|c|c|c|c|c|c|c|}
\hline \multicolumn{4}{|c|}{$\begin{array}{c}\text { Period 1991-2000 } \\
(n=399)(\text { sample } n=15)\end{array}$} & \multicolumn{4}{|c|}{$\begin{array}{c}\text { Period 2001-2010 } \\
(n=582)(\text { sample } n=62)\end{array}$} \\
\hline $\begin{array}{l}\text { Number } \\
\text { of } \\
\text { citations }\end{array}$ & $\begin{array}{l}\% \text { of } \\
\text { total }\end{array}$ & $\begin{array}{c}\% \text { of } \\
\text { sample }\end{array}$ & Authors & $\begin{array}{c}\text { Number } \\
\text { of } \\
\text { citations }\end{array}$ & $\begin{array}{l}\% \text { of } \\
\text { total }\end{array}$ & $\begin{array}{c}\% \text { of } \\
\text { sample }\end{array}$ & Authors \\
\hline 15 & 3.76 & 100 & Barney (1991) & 62 & 10.65 & 100 & Barney (1991) \\
\hline 9 & 2.26 & 60 & Porter (1985) & 23 & 3.95 & 271 & $\begin{array}{l}\text { Buckley \& Casson } \\
(1 y / 0)\end{array}$ \\
\hline$c$ & $1=n$ & in & $\begin{array}{l}\text { Johanson \& Vahlne } \\
\text { (1977) }\end{array}$ & 22 & 3.78 & 35.5 & $\begin{array}{l}\text { Johanson \& Vahlne } \\
\text { (1977) }\end{array}$ \\
\hline 6 & 1.50 & 40 & Porter (1980) & 19 & 3.26 & 30.6 & Wernerfelt (1984) \\
\hline 6 & 1.50 & 40 & Hymer (1976) & 17 & 2.92 & 27.4 & Kogut \& Singh (1988) \\
\hline 6 & 1.50 & 40 & Penrose (1959) & 16 & 2.75 & 25.8 & $\underset{(1993)}{\text { Kogut \& Zander }}$ \\
\hline 6 & 1.50 & 40 & Wernerfelt (1984) & 15 & 2.58 & 24.2 & Hymer (1976) \\
\hline 5 & 1 กร & 222 & $\begin{array}{l}\text { Bartlett \& Ghoshal } \\
\text { (1989) }\end{array}$ & 15 & 2.58 & 24.2 & $\begin{array}{l}\text { Teece, Pisano \& } \\
\text { Shuen (1997) }\end{array}$ \\
\hline 4 & 1.00 & 26.7 & Porter (1986) & 14 & 2.41 & 22.6 & Porter (1985) \\
\hline 4 & 1.00 & 26.7 & Kogut (1985) & 14 & 2.41 & 22.6 & Penrose (1959) \\
\hline 4 & 1.00 & 26.7 & Caves (1982) & 14 & 2.41 & 22.6 & Hofstede (1980) \\
\hline 4 & 1.00 & 26.7 & Collis (1991) & 14 & 2.41 & 22.6 & Dunning (1993) \\
\hline 4 & 1.00 & 26.7 & Hennart (1982) & 12 & 2.06 & 19.4 & Williamson (1985) \\
\hline$?$ & n 75 & nn & $\begin{array}{l}\text { Buckley \& Casson } \\
\text { (1976) }\end{array}$ & 12 & 2.06 & 19.4 & $\begin{array}{l}\text { Bartlett \& Ghoshal } \\
\text { (1989) }\end{array}$ \\
\hline 3 & 0.75 & 20 & Teece (1986) & 11 & 1.89 & 17.7 & $\underset{(1982)}{\text { Nelson \& Winter }}$ \\
\hline 3 & 0.75 & 20 & Kindleberger (1969) & 11 & 1.89 & 17.7 & $\begin{array}{l}\text { Hitt, Hoskisson \& Kim } \\
\text { (1997) }\end{array}$ \\
\hline 3 & 0.75 & 20 & Williamson (1985) & 11 & 1.89 & 17.7 & Caves (1982) \\
\hline 3 & 0.75 & 20 & Coase (1937) & 11 & 1.89 & 177 & $\underbrace{\text { Eisenhardt \& Martin }}_{(\angle U U U)}$ \\
\hline 2 & ก 75 & on & $\begin{array}{l}\text { Dierickx \& Cool } \\
\text { (1989) }\end{array}$ & 10 & 1.72 & 16.1 & $\begin{array}{l}\text { Dierickx \& Cool } \\
(1989)\end{array}$ \\
\hline 3 & 0.75 & 20 & Prahalad \& Doz (1987) & 10 & 1.72 & 16.1 & North (1990) \\
\hline
\end{tabular}

Note: $n$ - number of papers published in JIBS during the period. For instance, in the period 1991 to 2000 JIBS published 399 papers.

Source: citation data collected from ISI Web of Knowledge. Other computations by the authors. 
The list of the most cited works also reflects a mixed focus of IB-related research which deals with issues such as multinational enterprises, culture, RBV, knowledge and capabilities and the hazards of doing businesses abroad to point out the most prominent research themes. Moreover, albeit not surprising, the most cited works tend to be older works. Among the most cited in JIBS are Buckley and Casson (1976), Johanson and Vahlne (1977), Wernerfelt (1984), Kogut and Singh (1988), Hymer (1976) and Penrose (1959), all these published over 20 years ago.

Figure 2 shows the intellectual community, or the relational networks, on IB research. In this figure we used the co-authorships of the papers published that had two or more authors to draw the ties. Thicker lines connecting authors denote a larger number of papers coauthored and the relative diameter of the markers reveals the number of papers published and number of ties.

Examining figure 2 we identify four major networks. For example, one network includes Hooley, Shipley, Fahy, Cox, Beracs and Kolos' (1996) article on foreign investment and how firms may augment their pool of resources that they may use for domestic competition. It also includes Fahy, Hooley, Cox, Beracs, Fonfara and Snoj (2000) on the marketing capabilities. Both these articles have theoretical grounds on the RBV. Other network involves several different articles, such as Kotabe, Parente and Murray (2007), Kotabe, Srinivasan and Aulakh (2002), Gao, Murray, Kotabe and Jiangyong (2010) and Gubbi et al. (2010). This net is somewhat diverse in the themes delved but we may arguably identify a focus on perfomance issues for the multinationals, in export behaviors and R\&D. Kotabe, Parente and Murray (2007) specifically deal with a major issue in the current concerns: modularity in production - whose implications carry on to the usual offshoring and outsourcing dilemmas facing multinationals. Aulakh, Jiang and Pan (2010) research on international technology licensing, a topic that combines transaction costs issues with an RBV argument. In all these instances, the RBV clearly plays an important role. 


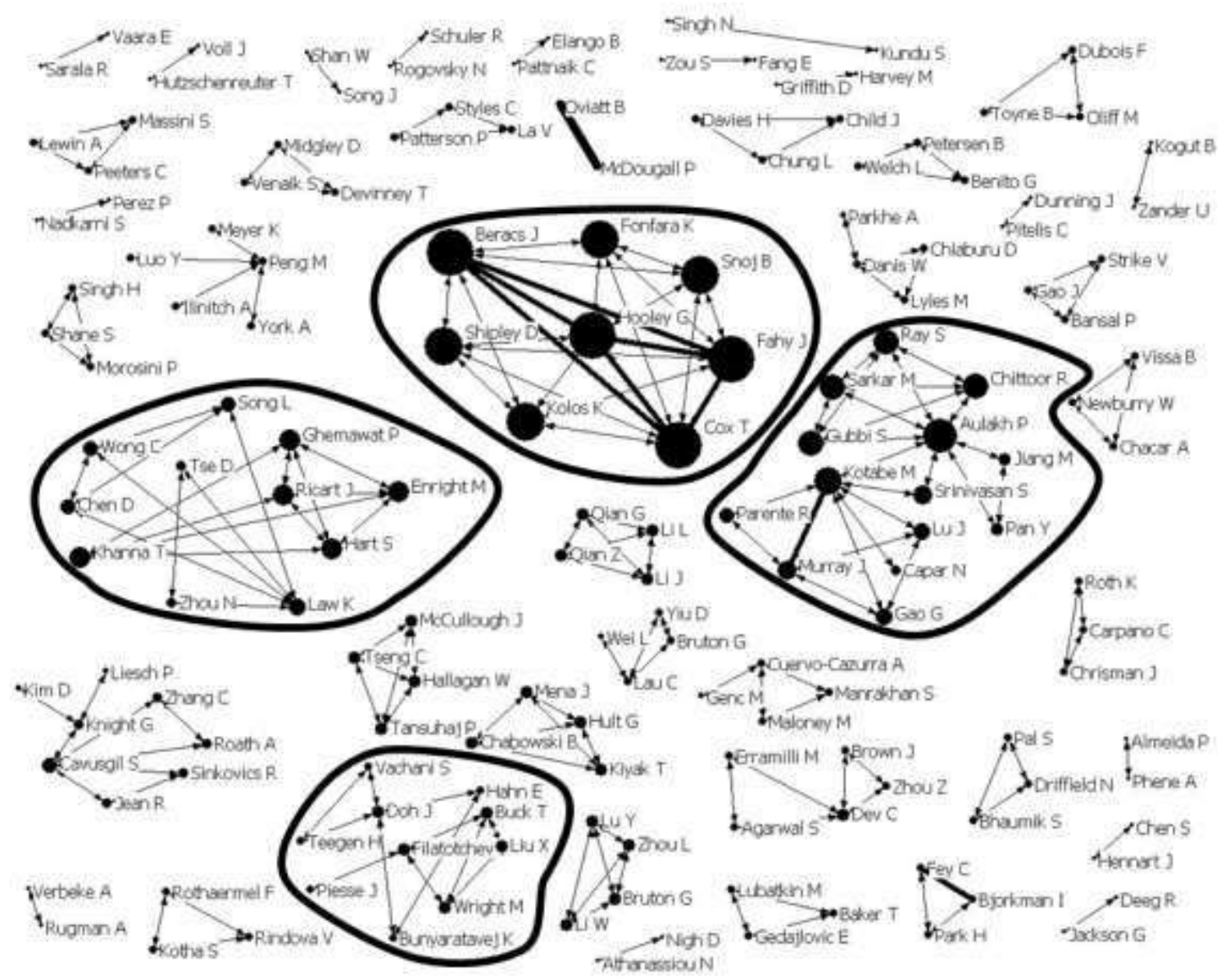

Figure 2 - Authorship relational networks

Note: Figure depicts co-authorships binding scholars that cited Barney's (1991) article.

Source: Data collected from ISI Web of Knowledge. Drawn with Ucinet.

The final analysis entailed identifying the research themes of the articles published (see Figure 3). The procedure, as explained previously, resorted to the analysis of the authorsupplied keywords, to infer the context in which Barney (1991) is cited. We proceed from the assumption that these keywords reflect the paper's content. Figure 3 depicts the network of themes identified on the papers citing Barney (1991). We should observe two basic features: first, the position of a given theme on the network - this reflects the relative frequency, such that more central themes are more often delved upon on the articles examined. The more frequent themes were 'Environmental, geography, clusters and regional', 'Capabilities, knowledge, resource-based view' and 'Internationalization, entry modes and strategic advantage' (see Appendix). Second, the thickness of the lines represents the frequency with which a pair of themes is examined. 


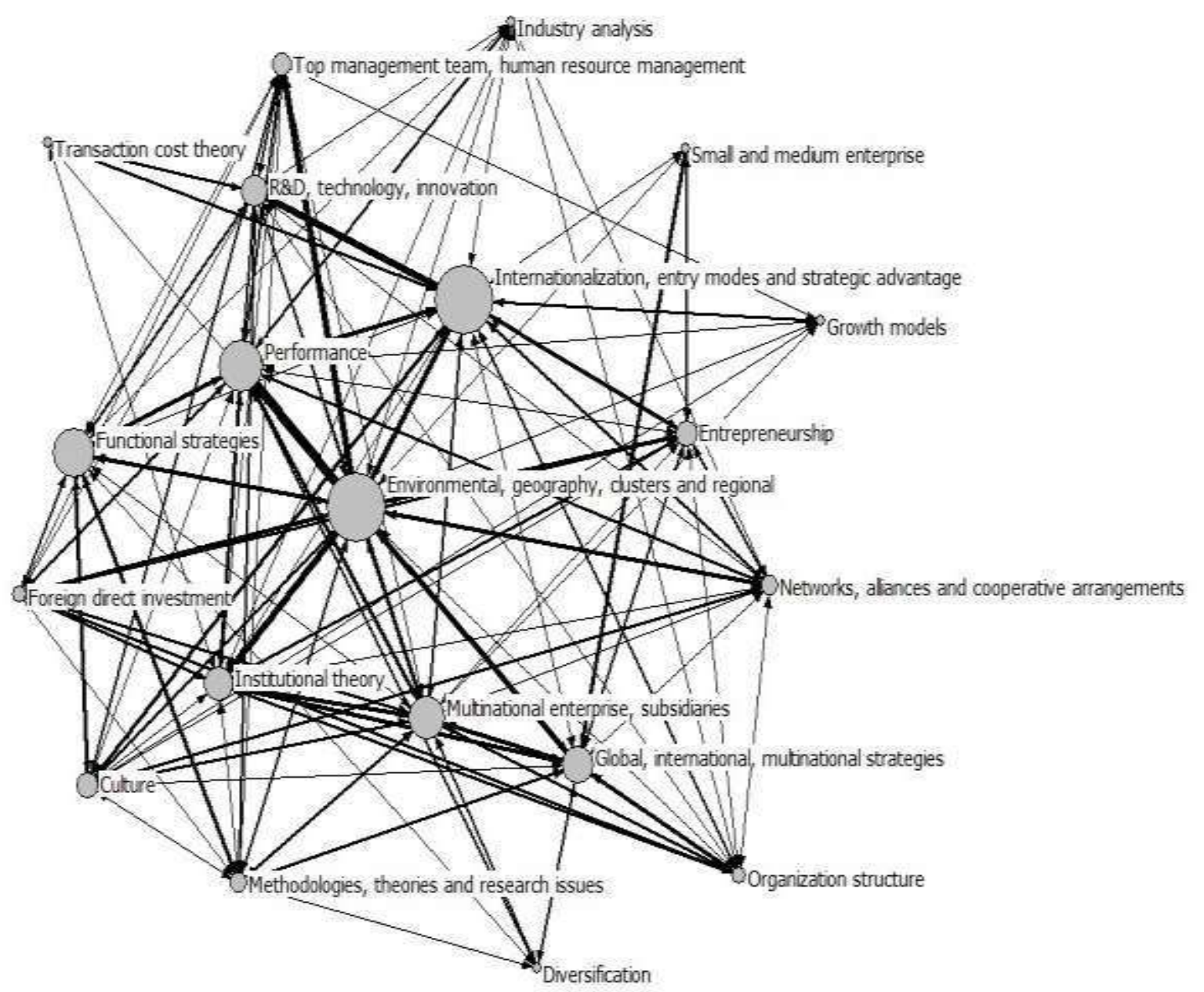

Figure 3 - Major research themes

Source: data collected from ISI Web of Knowledge. Data organized using Bibexcel and figure drawn using Ucinet.

Since our focus is on the RBV, using Barney's (1991) article as the marker, we do not include the theme 'Capabilities, knowledge, resource-based view' in the visual representation of the map, which would appear in a central position. At the core of the network we observe three themes that have the highest frequency: "Environmental, geography, clusters and regional", "Internationalization, entry modes and strategic advantage" and "Performance". These may not be surprising since "Environmental, geography, clusters and regional" is also a central theme on IB-related research, namely since IB research deals with firms operating in different international business environments, the choice of foreign locations and even the focus of a portion of research on how firms select locations of excellence, such as industry clusters, to learn and augment capabilities they already hold (FERREIRA, 2008; TALLMAN; FLADMOE-LINDQUIST, 2008). Contributing to this upsurge are studies on emerging economies and such countries as China, albeit this is not a completely novel trend. "Performance" issues are often delved upon as a dependent variable since scholars seek to augment firms' performance by establishing better manners to operate, best locations, 
solutions that decrease costs, and so forth. "Internationalization, entry modes and strategic advantage" are at the very core of the discipline and is one of the most traditional, or classical, lenses in IB research, encompassing a variety of decisions and phenomena from the entry mode choices to how firms may explore or exploit they advantages abroad. Often, this research has taken an RBV approach. The RBV has also been used in researching 'Internationalization, entry modes and strategic advantage' namely in what concerns the evaluation of firms' resources for internationalizing, which has often been treated looking at the firms' ability to transfer firm-specific advantages. The focus on strategic advantage is not surprising as it is an evidence of a firm level focus, and specifically a focus on performance that characterize much of the strategic management research.

\section{FINAL DISCUSSION AND CONCLUDING REMARKS}

In this paper we aimed at understanding the influence of RBV in international business research. Methodologically, we specifically used Jay Barney's (1991) article "Firm resources and sustained competitive advantage" as a key marker for the RBV and assessed how much and in which conditions it has been utilized by IB scholars over the last two decades. Notwithstanding, an upfront remark must be made: we do not intend to make a full praise to Barney's work and we acknowledge that there are many other very relevant articles, books and authors both at the origin of an RBV perspective as well as contributing to its development over the years. In any case, we also acknowledge that Barney's (1991) article is one of the most cited in management/business studies with over five thousands citations (data collected from ISI knowledge).

In this paper we contribute to better understand how the RBV has been used in the extant IB research, thus complementing existing studies (e.g., ACEDO et al., 2001; ACEDO; BARROSO; GALAN, 2006; PENG, 2001; NEWBERT, 2007; KRAAIJENBRINK, et al., 2010). We started by clearly noting the weight of RBV-related research in IB by identifying those papers published in the leading journal for IB studies. It is clear the growing trend over time in research using RBV in IB studies; nonetheless only about ten per cent of the more recent articles used the RBV. We then mapped the intellectual ties binding scholars and their works, using co-citation analysis, to unveil how these works intertwine in the discipline. The relational networks among authors permit us identify clusters of more prolific scholars and groups. We conclude identifying the concentration of themes and how they relate. To a large extent these analyses permit us to grasp some of the main trends that occurred and arguably capture the matrix of how RBV and its variants have disseminated in IB research. Hence, this 
work also entails a contribution towards understanding the intellectual roots of the topic in the discipline. Our results provide some insights on areas that have been less studied using RBV lens and that may prove munificent areas for future scholarly inquiry, especially for newer colleagues and recent graduates that seek to identify gaps in the current knowledge. Finally, our study contributes to form a better picture on the tentacles of the RBV in IB, as it permeates a variety of phenomena.

\subsection{THE RBV IS NOT SO NEW IN IB STUDIES}

The RBV posits that firms must possess valuable, rare, imperfectly imitable and nonsubstitutable resources to gain and sustain a competitive advantage. The RBV is recognized as retaining increasing attention in IB research (PENG, 2001). The augment in the use of RBV is largely due to the increasing acceptance not only of the theory but also of the focus on internal factors to the firm. To some extent this is a reflection of the focus on the firm, the multinational firm, and the quest to understand how multinational firms compete in the foreign markets entered. Moreover, a core condition for the internationalization of the multinational is holding some competitive advantage that it may exploit in the foreign markets. Nonetheless, in at least some instances, firms may expand abroad also to augment their pool of resources and capabilities that may leverage an advantage. Hence, when looking at IB research we should probably take a wider perspective of the RBV to include such issues as learning (FOSS; PEDERSEN, 2004), the evolutionary perspectives (e.g., KOGUT; ZANDER, 1993), and the dynamic capabilities views (SAPIENZA et al., 2006) all of which are relevant in current research.

We identified a growth in the volume of RBV-related research in IB studies. The impact of the RBV on IB research probably reflects that a large portion of IB research may be classified as international strategy and focuses on how firms and managers act to reshuffle competition (e.g., DESS et al., 1995; TALLMAN; LI, 1996; MJOEN; TALLMAN, 1997;

VERMEULEN; BARKEMA, 2001). That is, the emergence of the RBV as an influential perspective is part of the well-known evolution IB has witnessed over the last three decades. First the focus shifted from economic issues and variables to the transactions (WILLIAMSON, 1975; HENNART, 1982) and more recently to the firm (e.g., BARTLETT; GHOSHAL, 1989; DOZ, 1997; PENG, 2001). The RBV has been the protagonist taking a leading role in this shift and signals scholars' attention in firms-specific resources, capabilities, competences or knowledge as sources of competitive advantage; in a contrast to industry or country level factors. 
The RBV has had a pervasive influence in an array of research themes pertaining to IB (see figure 3). Perhaps more remarkable has been on understanding how firms' resources and capabilities may develop locally, either in the hoe or host country, and how may firms transfer those resources/capabilities to other foreign operations bettering the overall operations and performance of the multinational. To some extent, we observe the ties to the institutional theory and the broader environmental factors, but we also observe the ties to yet less explored aspects of how may multinationals develop collaboratively those resources. Interesting in this respect is how little we master on firms' ability to leverage their current pool of resources to diversify business-level operations.

The fact, as noted in Peng (2001), is that IB scholars have also made some contributions to the development of RBV and its variants. For instance, the contributions by Kogut and Zander (1993) and Meyer and Peng (2005) help better understand the evolutionary perspective and what constitute VRIN resources. For instance, identifying international knowledge and experience as a valuable, unique, and difficult to imitate resource (HITT et al., 2006) that may support a competitive advantage. In fact, the IB perspective of examining internationalization as an incremental process (JOHANSON; VAHLNE, 1977) comprises the idea that firms hold a home country based advantage that, at least in part, is already a recognition of firms-specific advantages (see also HYMER's (1976) seminal work). Indeed, Peng (2001) and Sapienza et al. (2006) noted how the heterogeneous resources assumption that is foundational to the RBV is well embedded in IB research.

\subsection{AREAS OF RESEARCH AND GAPS}

Our analyses help us define many areas and gaps that warrant additional research and from which we may gain a better understanding to answer to Peng's (2004) plight: What determines the international success and failure of firms? The RBV proposes that firms' competitive advantage derives from their pool of resources and capabilities, most especially when these fulfill four requirements: value, rarity, non-imitability and non-substitutability (BARNEY, 2001). To a large extent this view, that became either complementary or clashing to industrial organization perspectives (PORTER, 1980), permitted to explain why there are performance differences across firms (BARNEY, 2001). Rumelt (1991), for instance, studying US firms, found that industry conditions explained a mere $4 \%$ of profitability differences, while firm level factors, or resources, explained $44 \%$ of the variations. Lopez (2001), using a sample of Spanish firms, also found that the industry accounted for only 3\% of the performance variation and firms' resources accounted for $36 \%$. 
Research using an RBV approach has targeted mainly such themes as performance, internationalization and entry modes, multinational enterprises and subsidiaries, environmental and geographies (see Figure 3). Conversely, it has taken less attention to such issues as Diversification, culture, TMT and human resources, small and medium enterprises and entrepreneurship, networks, and so forth. It is interesting, in this respect to note that Peng (2001) argued the contribution of the RBV for the study of multinationals and foreign market entry modes, which we confirm. However, how has the RBV been incorporated in such studies? Our analyses highlight possible explanations. To the entry modes research, the RBV offers lenses targeted at examining firms' specific advantages built of resources and capabilities that guide the selection of the entry mode. Even the literature on born globals or on the internationalization since inception - that is one of the streams in international entrepreneurship - may be examined assessing the resources and capabilities, or the knowledge, held by these firms that provide them some form of advantage, despite the liabilities of newness and foreignness.

However, Peng (2001) also noted the enrichment of areas such as partnering, entrepreneurship and emerging markets, albeit we fail to find that evidence. Notwithstanding, we may identify how such research could proceed. For instance, partnering and networking are vehicles for accessing resources not yet held, and an accurate evaluation of the partners' potential contribution to the collaboration is crucial for its future success. Many of the networks and collaborative agreements are set in knowledge-intensive industries in which firm capabilities matter (KOGUT; ZANDER, 1993) and these networks permit access resources complementary to the pool already held. Moreover, when entering emerging markets, firms may partner as a manner to overcome market imperfections and the insufficiencies of an underdeveloped institutional environment. The pool of partnerships may be in itself a strategic resource.

The results show that research on the Top Management Teams (TMT) and human resource management is still needed of further attention. A possible avenue, using an RBV approach is on how a core source of firms' advantage may lie on the managers' international experience, and how it provides a capability of operating in foreign countries (FERREIRA, 2008).

Location decisions is a core theme to IB research and one of the three pillars of Dunning's eclectic paradigm. Over the past two decades IB scholars have sought to understand the impact of the host country institutional environment on an array of decisions 
and strategies (NORTH, 1990; OLIVER, 1997; MEYER, 2001; MEYER et al., 2009). To some extent, this line of research has distinguished operating in developed versus emerging or transition economies (FERREIRA; LI; JANG, 2009; MEYER et al., 2009) and Hoskisson et al. (2000) discussed how firm-specific resources that provide an advantage in developed countries may not hold an equal value when operating in transition economies. It is possible that, at least in some instances, firms need to partner with others to access the needed resources in these environments. How host country institutional environments are evolving, especially in the emerging economies and how firms strategize for entering these environments may benefit from using the RBV as the conceptual perspective. This line of enquiry may be related to the theme on $R \& D$, technology and innovation namely on how firms internationalize to procure innovation and innovative ability, perhaps using the knowledge-based view of the multinational (see KOGUT; ZANDER, 1992, 1993).

The stream of research on the internationalization, entry modes and strategic advantage (see figure 3) is well represented in our results. This is not surprising since ownership advantages as a core condition for internationalization have been long understood by IB scholars. The Uppsala model of internationalization as a gradual process (e.g., JOHANSON; VAHLNE, 1977) relies on the accumulation of knowledge and a capability-based understanding of how to operate in a foreign market. In fact, often firms' advantages are specific to their home countries. Nonetheless, future research may better explore the type of resources and capabilities worthwhile developing internally, which to procure in the foreign countries (thus partly explaining foreign direct investment) and how specifically they come into play regarding entry mode selection.

The resources and capabilities held are critical to understanding firms' international activities. For example, presiding to the selection of the entry mode are the pool of resources required by the operation itself. The decision to carry the foreign operations internally or contracting them to an independent provider relies on the potential for attaining a competitive advantage or overcoming transaction costs. Firms prefer to internalize operations - and carry out foreign direct investment - when their advantage may be eroded by opportunistic partners or is difficult to transfer. This stream of research may be complemented with a transaction costs approach.

The themes on small and medium enterprises and on entrepreneurship are also reasonably underexplored. Using the RBV possible future research avenues may entail understanding what are the resources and capabilities that small or new firms need to 
successfully compete in the global marketplace. That is, how can these small or new firms compete against large multinationals in foreign countries. It is likely that part of the answer is on selecting market niches that multinationals do not tap into. Another approach may delve into specific capabilities, hardly experiential, that render small firms larger flexibility to proceed with adjustments to the host country, something that multinationals with standardized offerings find hard to accomplish.

A wealth of other themes warrant additional research. For instance, the theme on multinationals and subsidiaries, is still reasonably scarce on understanding how better arrange internally knowledge transfer flows and the coordination and incentive mechanisms required. Also, albeit the liability of foreignness and the impact of operating in culturally distant countries (KOGUT; SINGH, 1988) are well known, research on how home-based firmspecific advantages may be tailored to operating in a different country is less comprehended. For instance, when facing countries culturally distant, firms respond by selecting low involvement entry modes, but this choice prevents many firms from fully capturing potential rents. The ability to operate effectively in different national environments is a capability, but seldom firms actively plan to develop such a capability.

\subsection{LIMITATIONS}

Our study is restricted to a single journal - JIBS - which is a limitation. JIBS is the leading journal in the discipline and arguably will capture the most significant streams of research being carried out. Other IB and business/management journals also publish IBrelated research, perhaps with different emphasis or orientations that may influence the theoretical frameworks and perspectives scholars use. Still we are confident that the goal of our study is met with a sample of articles from the top IB journal which is expected to represent the state of the art of the discipline. Nonetheless, in future research we may broaden our analysis to include other journals which may allow us to detect whether there are other patterns and connections pertaining to the impact of the RBV on IB studies. Even so, focusing on the leading journal is appealing because top journals are more likely to publish groundbreaking works which punctuate the intellectual development of a discipline. On the other hand, by maintaining the study to a single journal we avoid biases emerging from editorial policies or regional interests. To conclude, it is worth noting that JIBS, compared to other IB-specific journals has the largest track record of publications available in ISI web of knowledge. For instance, International Business Review, the journal of the European International Business Academy, is available only since 2005, the Journal of International 
Management is available since 2007, the European Journal of International Management is available since 2008 and Management International Review, albeit founded in 1966 has a large gap in which it was not included in ISI.

The extant IB literature has many examples of reviews using different methods. Bibliometric studies are less common and the techniques we used to assess the impact of an author or topic in a discipline are also fairly uncommon. However, the method is not immune to drawbacks. Citation and co-citation analyses may be somewhat biased towards older, established, works. The fact is that, other things constant, older works tend to be more cited than more recent works. Nonetheless, we should point that our purpose was not to observe citations to Barney's (1991) article but rather we used this work as a key marker for the RBV. Citation and co-citation analyses also do not permit us an absolutely clear understanding of the context in which a citation is made. It is well known that a citation may be made for multiple purposes, in some instances to build an argument, in other situations to critique. For example, we noted that RBV and TCT works are often co-cited which is explained by scholars comparing the different predictions of different theories for a given phenomenon (e.g., MADHOK, 1997). In other instances, the critiques to a theory are a manner to reveal a gap and advance novel approaches. These gaps may be positioned as the research question in a paper. This limitation may be overcome in future research by conducting an in-depth literature review, with a content analysis, to ascertain what is the evolution in the use of the $\mathrm{RBV}$ in IB research, differences in the methods used over time and even how the RBV has been applied to different issues.

It is further worth noting that using ISI web of knowledge as the source of the data for the bibliometric study may also entail a limitation. Albeit ISI web of knowledge is one of the leading and widely utilized databases for scholarly research, with a tie to the Journal Citation Report, it only permits that we search each journal for articles in a selected number of "fields". Specifically, the mining tools available conduct the search in the fields: title, abstract, author-supplied keywords and the keywords generated by ISI, not in the full text of the manuscript. This limitation may be overcome by employing alternative search engines and databases such as Scopus. However, after some exploratory tests (not reproduced here) and since our focus on only one journal the size of the database of journals involved is not as relevant. Possible differences seem minor not affecting our confidence that our sample is a good representation of the research conducted and adequate for this bibliometric study. 
We also recognize the limitation concerning how we proxied the themes researched. While we used the articles' author-supplied keywords to extrapolate content, following the procedure in Furrer, Tomas and Goussevskaia (2008), the keywords may not clearly describe the content of a paper which would render an incomplete analysis. Moreover, it is worth noting that following Furrer et al.'s (2008) procedure may bring about some overlap between some of the themes. This is an issue whereby we may face lower than desired discriminant validity of the construct that may lower the strength of some constructs (themes) shown in Figure 3. One example is the theme "Environmental, geography, clusters and regional" where we find some keywords that are not completely dissociated from other possible themes such as Culture" and "Diversification". Despite this limitation, we are confident that such potential overlapping does not substantially alter the conclusions we draw. Thus, future research may develop other procedure to infer the themes, or content, of the articles, namely using content analysis software.

Finally, our purpose was to delve into the RBV and understand how it has been used in IB research. A more complete understanding of IB as a field of study could be captured in future research by widening the analyses to include comparisons to other theories. For instance, comparing the impact of RBV and other theories such as TCT or institutional theory could be appealing.

\subsection{CONTRIBUTION}

Papers conducting bibliometric analyses of the extant research may be of particular use for new researchers and masters and doctoral students. Not only may they learn about the past research but also who are the most relevant authors and works and the research themes. Albeit

our analyses do not exclude the readers' own interpretation of the results, they may learn on areas that have been relatively less delved into and be possible paths to develop future studies.

Understanding the impact of the RBV is particularly useful for understanding firms' resources and capabilities firms hold and that they may either exploit in national and international settings but also to figure out which resources and capabilities they need to develop to compete. In an IB context the RBV may offer clues decisive for such disparate decisions as the choice of location, entry mode to use, the best partner for an alliance or an international joint venture. All in all, RBV offers practitioners and strategists a framework to ascertain the strengths and weaknesses of the firm.

There is much to be attained in the realm of IB research using the RBV. For practitioners may be especially important to develop schemas that permit managers 
identifying the resources that are more valuable in each foreign country. Given that different countries have different institutional settings and competition rules, hardly the same pool of firm-specific resources will have equal value in every country. In a similar vein, which of the firms' resources are truly valuable for supporting international diversification. And, which resources should the multinationals seek to augment and transfer internally to other subsidiaries in different countries. This latter is particularly relevant for subsidiary managers that need to promote mechanisms for both the absorption and the transfer of knowledge internally and to other subsidiaries.

This paper, as any literature review regardless the method used, offers researchers a broad image of the state of the art in a field of study. By proxying the RBV using Barney's (1991) paper we did not intend to capture all RBV-based research but simply to obtain a clear picture of the evolution. The fact is that IB has evolved also because of the insights provided by the RBV especially on how to look inside the firm and what we should look for, in contrast to the traditional emphasis on the industry or the broader surrounding milieu. The study of investment decisions, location, entry modes, multinationals and subsidiaries has greatly benefited from making use of RBV framework. Notwithstanding, there is still much to be further examined to actually gain a full understanding of firms' international operations.

\section{REFERENCES}

ACEDO, F.; BARROSO, C.; CASILLAS, J.; GALAN, J. Dominant approaches in the field of management. International Journal of Organizational Analysis, v. 9, n. 4, p. 327-353, 2001.

ACEDO, F.; BARROSO, C.; GALAN, J. The resource-based theory: Dissemination and main trends. Strategic Management Journal, v. 27, p. 621-636, 2006.

AMIT, R.; SCHOEMAKER, P. Strategic assets and organizational rent. Strategic Management Journal, v. 14, p. 33-46, 1993.

ANDERSON, E.; GATIGNON, H. Modes of foreign entry: A transaction cost analysis and propositions. Journal of International Business Studies, v. 17, n. 3, p. 1-26, 1986.

AULAKH, P.; JIANG, M.; PAN, Y. International technology licensing: Monopoly rents, transaction costs and exclusive rights, Journal of International Business Studies, v. 41, n. 4, p. $587-605,2010$.

BAIN, J. Industrial organization. New York, NY: John Wiley, 1968.

BARNEY, J. Firm resources and sustained competitive advantage. Journal of Management, v. 17, n. 1, p. 99-120, 1991. 
2002.

Gaining and sustaining competitive advantage, New York, NY: Prentice Hall,

Strategic factor markets. Management Science, v. 32, n. 10, p. 1231-1241, 1986.

BARNEY, J.; WRIGHT, M.; KETCHEN, D. The resource-based view of the firm: ten years after 1991. Journal of Management, v. 27, n. 6, p. 625-641, 2001.

BARTLETT, C.; GHOSHAL, S. Managing across borders: The transnational solution. Boston, MA: Harvard Business School Press, 1989.

BEAUDRY, P.; DUPAIGNE, M.; PORTIER, F. Modeling news-driven international business cycles. Review of Economic Dynamics, v. 14, n. 1, p. 72-91, 2011.

BIRKINSHAW, J.; HOOD, N. Multinational subsidiary evolution: Capability and charter change in foreign-owned subsidiary companies. Academy of Management Review, v. 23, n. 4, p. 773-795, 1998.

BRANNEN, M.; DOZ, Y. From a distance and detached to up close and personal: Bridging strategic and cross-cultural perspectives in international management research and practice. Scandinavian Journal of Management, v. 26, n. 3, p. 236-247, 2010.

BUCKLEY, P.; CASSON, M. The future of the multinational enterprise. London: Macmillan, 1976.

BUCKLEY, P.; CHAPMAN, M. Theory and method in international business research. International Business Review, v. 5, n. 3, p. 233-245, 1996.

BUCKLEY, P.; PASS, C.; PRESCOTT, K. The internationalization of service firms: a comparison with the manufacturing sector. Scandinavian International Business Review, v. 1, n. 1, p. 39-56, 1992.

CHANDRA, R.; NEWBURRY, W. A cognitive map of the international business field. International Business Review, v. 6, n. 4, p. 387-410, 1997.

CHANG, S. International expansion strategy of Japanese firms: Capability building through sequential entry. Academy of Management Journal, v. 38, n. 2, p. 383-407, 1995.

CZINKOTA, M.; ROAKAINEN, I. International business and trade in the next decade: Report from a Delphi study. Journal of International Business Studies, v. 28, n. 4, p. 827844, 1997.

DAS, T.; TENG, B. A resource-based theory of strategic alliances. Journal of Management, v. 26, n. 1, p. 31-61, 2000.

DESS, G.; GUPTA, A.; HENNART, J.-F.; HILL, C. Conducting and integrating strategy research at the international, corporate, and business levels. Journal of Management, v. 21, n. 3, p. 357-393, 1995.

DIERICKX, I.; COOL, K. Asset stock accumulation and sustainability of competitive advantage. Management Science, v. 35, n. 12, p. 1504-1511, 1989. 
DIODATO, V. Dictionary of bibliometrics. Binghamton, NY: Haworth Press, 1994.

DOH, J. Offshore outsourcing: Implications for international business and strategic management theory and practice. Journal of Management Studies, v. 42, n. 3, p. 695-704, 2005.

DOZ, Y. Strategic management and international business research: An empirical convergence? In: TOYNE, B.; NIGH, D. (Eds.). International business: An emerging vision. Columbia, SC: University of South Carolina Press, 1997. p. 488-497.

DUBOIS, F.; REEB, D. Ranking the international business journals, Journal of International Business Studies, v. 31, n. 4, p. 689-704, 2001.

DUNNING, J.; PITELIS, C. Stephen Hymer's contribution to international business scholarship: An assessment and extension. Journal of International Business Studies, v. 39, p. 167-176, 2008.

FAHY, J.; HOOLEY, G.; COX, T.; BERACS, J.; FONFARA, K.; SNOJ, B. The development and impact of marketing capabilities in Central Europe. Journal of International Business Studies, v. 31, n. 1, p. 63-81, 2000.

FERREIRA, M. A bibliometric study on Ghoshal's managing across borders, Multinational Business Review, v. 19, n. 4, p. 357 - 375, 2011.

Building and leveraging knowledge capabilities through cross border acquisitions: The effect of the multination corporation's capabilities and knowledge strategy on the degree of equity ownership. 2005. Unpublished Doctoral dissertation, The University of Utah, EUA, 2005.

FERREIRA, M. Building and leveraging knowledge capabilities through cross-border acquisitions. In: TALLMAN, S. (Ed.). New generations in international strategy. Edward Elgar Publishing, Ltd, 2008.

FERREIRA, M.; LI, D.; JANG, Y. Foreign entry strategies: strategic adaptation to the various facets of the institutional environments. Development and Society, v. 38, n. 1, p. 27-55, 2009.

FERREIRA, M.; SERRA, F. Make or buy in a mature industry? Models of client-supplier relationships under TCT and RBV perspectives. Brazilian Administration Review (BAR), v. 7, n. 1, p. 22-39, 2010.

FOSS, N.; PEDERSEN, T. Organizing knowledge processes in the multinational corporation: An introduction. Journal of International Business Studies, v. 35, p. 340-349, 2004.

FURRER, O.; TOMAS, H.; GOUSSEVSKAIA, A. The structure and evolution of the strategic management field: A content analysis of 26 years of strategic management research. International Journal of Management Reviews, v. 10, n. 1, p. 1-23, 2008.

GAO, G.; MURRAY, J.; KOTABE, M.; JIANGYONG, L. A "strategy tripod" perspective on export behaviors: Evidence from domestic and foreign firms based in an emerging economy. Journal of International Business Studies, v. 41, n. 3, p. 377-396, 2010. 
GELBUDA, M.; MEYER, K.; DELIOS, A. International business and institutional development in central and eastern Europe. Journal of International Management, v. 14, n. 1, p. 1-12, 2008.

GRANT, R. The resource-based theory of competitive advantage: implications for strategy formulation. California Management Review, Spring, p. 114-135, 1991.

Toward a knowledge-based theory of the firm. Strategic Management Journal, v. 17, p. 109-122, 1996.

GUBBI, S.; AULAKH, P.; RAY, S.; SARKAR, M.; CHITTOOR, R. Do international acquisitions by emerging economy firms create shareholder value? The case of Indian firms. Journal of International Business Studies, v. 41, p. 397-418, 2010.

GULATI, R.; LAVIE, D.; SINGH, H. The nature of partnering experience and the gains from alliances. Strategic Management Journal, v. 30, n. 11, p. 1213-1233, 2009.

GUPTA, A.; GOVINDARAJAN, V. Knowledge flows within multinational corporations. Strategic Management Journal, v. 21, n. 4, p. 473-496, 2000.

HAMEL, G. Competition for competence and inter-partner learning within international strategic alliances. Strategic Management Journal, v. 12, p. 83-103, 1991.

HAMEL, G.; PRAHALAD, G. Competing for the future. Boston, MA: Harvard Business School Press, 1994.

HELFAT C.; LIBERMAN B. The birth of capabilities: Market entry and importance of prehistory. Industrial and Corporate Change, v. 19, n. 6, p. 725-760, 2002.

HELFAT, C.; PETERAF, M. The dynamic resource-based view: Capability lifecycles. Strategic Management Journal, v. 24, p. 997-1010, 2003.

HENNART, J-F. A theory of multinational enterprise. Ann Arbor (MI): University Of Michigan Press, 1982.

HITT, M.; BIERMAN, L.; UHLENBRUCK, K.; SHIMIZU, K. The importance of resources in the internationalization of professional service firms: The good, the bad, and the ugly. Academy of Management Journal, v. 49, p. 1137-1157, 2006.

HITT, M.; DACIN, M.; LEVITAS, E.; ARREGLE, J-L.; BORZA, A. Partner selection in emerging and developed market contexts: Resource-based and organizational learning perspectives. Academy of Management Journal, v. 43, n. 3, p. 449-467, 2000.

HITT, M.; HOSKISSON, R.; KIM, H. International diversification: Effects on innovation and firm performance in product-diversified firms. Academy of Management Journal, v. 40, n. 4, p. 767-798, 1997.

HOOLEY, G.; SHIPLEY, D.; FAHY, J.; COX, T.; BERACS, J.; KOLOS, K. Foreign direct investment in Hungary: Resource acquisition and domestic competitive advantage. Journal of International Business Studies, v. 27, n. 4, p. 683-709, 1996. 
HOSKISSON, R.; EDEN, L.; LAU, C-M.; WRIGHT, M. Strategies in emerging economies. Academy of Management Journal, v. 43, n. 3, p. 249-267, 2000.

HYMER, S. The international operations of national firms. Cambridge, MA: MIT Press, 1976.

INKPEN, A.; BEAMISH, P. An analysis of twenty-five years of research in the Journal of International Business Studies. Journal of International Business Studies, v. 25, p. 703 713, 1994.

JOHANSON, J.; VAHLNE, J. The internationalization process of the firm: A model of knowledge development and increasing foreign market commitment. Journal of International Business Studies, v. 8, p. 22-32, 1977.

JONES, M.; COVIELLO, N.; TANG, Y. International entrepreneurship research (19892009): A domain ontology and thematic analysis. Journal of Business Venturing, v. 26, n. 6, p. 632-659, 2011.

KOGUT, B. The evolutionary theory of the multinational corporation. In: TOYNE, B.; NIGH, D. (eds.). International business: An emerging vision. Columbia, SC: University of South Carolina Press, p. 470-488, 1997.

KOGUT, B.; ZANDER, U. Knowledge of the firm, combinative capabilities, and the replication of technology. Organization Science, v. 3, p. 383-397, 1992.

;. Knowledge of the firm and the evolutionary theory of the multinational corporation. Journal of International Business Studies, v. 24, p. 625-645, 1993.

KOSTOVA, T.; ZAHEER, S. Organizational legitimacy under conditions of complexity: The case of the multinational enterprise. Academy of Management Review, v. 24, p. 64-81, 1999.

KOTABE, M.; PARENTE, R.; MURRAY, J. Antecedents and outcomes of modular production in the Brazilian automobile industry: A grounded theory approach. Journal of International Business Studies, v. 38, n. 1, p. 84-106, 2007.

KOTABE, M.; SRINIVASAN, S.; AULAKH, S. Multinationality and firm performance: The moderating role of R\&D and marketing capabilities. Journal of International Business Studies, v. 33, n. 1, p. 79-97, 2002.

LEONIDOU, L.; KATSIKEAS, C.; COUDOUNARIS, D. Five decades of business research into exporting: A bibliographic analysis. Journal of International Management, v. 16, n. 1, p. 78-91, 2010.

LI, D.; FERREIRA, M. Institutional environment and firms' sources of financial capital in Central and Eastern Europe. Journal of Business Research, v. 64, n. 4, p. 371-376, 2010.

LOCKETT, A.; THOMPSON, S.; MORGENSTERN, U. The development of the resourcebased view of the firm: A critical appraisal. International Journal of Management Reviews, v. 11, n. 1, p. 9-28, 2009. 
LOPEZ, V. An overview review of the Resource-Based View of the firm, drawing on recent Spanish management research. Irish Journal of Management, v. 22, n. 2, p. 105-120, 2001.

LU, J. The evolving contributions in international strategic management research. Journal of International Management, v. 9, n. 2, p. 193-213, 2003.

MADHOK, A. Cost, value, and foreign market entry mode: The transaction and the firm. Strategic Management Journal, v. 18, n. 1, p. 39-61, 1997.

MAHONEY, J.; PANDIAN, J. The resource-based view within the conversation of strategic management. Strategic Management Journal, v. 13, p. 363-380, 1992.

MCDOUGALL, P.; SHANE, S.; OVIATT, B. Explaining the formation of international new ventures: The limits of theories from international business research. Journal of Business Venturing, v. 9, n. 6, p. 469-487, 1994.

MEYER, K. Institutions, transaction costs, and entry mode choice in Eastern Europe. Journal of International Business Studies, v. 32, n. 2, p. 357-367, 2001.

MEYER, K.; ESTRIN, S.; BHAUMIK, S.; PENG, M. Institutions, resources and entry strategies in emerging economies. Strategic management journal, v. 30, n. 1, p. 61-80, 2009.

MEYER, K.; PENG, M. Probing theoretically into Central and Eastern Europe: Transactions, resources, and institutions. Journal of International Business Studies, v. 36, p. 600-621, 2005.

NEWBERT, S. Empirical research on the Resource Based View of the firm: An assessment and suggestions for future research. Strategic Management Journal, v. 28, p. 121-146, 2007.

NORTH, D. Institutions, institutional change and economic performance. Cambridge, MA: Cambridge University Press, 1990.

OLIVER, C. Sustainable competitive advantage: Combining institutional and resource-based views. Strategic Management Journal, v. 18, n. 9, p. 697-713, 1997.

OVIATT, B.; MCDOUGALL, P. Toward a theory of international new ventures. Journal of International Business Studies, v. 25, p. 45-64, 1994.

PENG, M. Identifying the big question in international business research. Journal of International Business Studies, v. 35, p. 99-108, 2004.

PENG, M. The resource-based view and international business. Journal of Management, v. 27, n. 6, p. 803-829, 2001.

PENROSE, E. The theory of the growth of the firm. New York, NY: Oxford University Press, 1959.

PETERAF, M. The cornerstones of competitive advantage: A resource-based view. Strategic Management Journal, v. 14, n. 3, p. 179-191, 1993. 
PETERAF, M.; BARNEY, J. Unraveling the resource-based tangle. Managerial and Decision Economics, v. 24, p. 309-323, 2003.

PHELAN, S.; FERREIRA, M. P.; SALVADOR, R. The first twenty years of the Strategic Management Journal: 1980-1999. Strategic Management Journal, v. 23, p. 1161-1168, 2002.

PHENE, A.; GUISINGER, S. The stature of the Journal of International Business Studies, Journal of International Business Studies, v. 29, n. 3, p. 621-632, 1998.

PITELIS, C. Edith Penrose and the resource-based view of (international) business strategy. International Business Review, v. 13, n. 4, p. 523-532, 2004.

PORTER, M. Competitive strategy: Techniques for analyzing industries and competitors. New York, NY: Free Press, 1980.

PORTER, M. How competitive forces shape strategy. Harvard Business Review, p. 137145, mar./abr. 1979.

PRAHALAD, C.; HAMEL, G. The core competence of the corporation. Harvard Business Review, v. 68, p. 79-91, 1990.

PRIEM, R.; BUTLER, J. Is the resource-based "view" a useful perspective for strategic management research? Academy of Management Review, v. 26, n. 1, p. 22-40, 2001.

RAMOS-RODRIGUEZ, A.; RUIZ-NAVARRO, J. Changes in the intellectual structure of strategic management research: A bibliometric study of the Strategic Management Journal, 1980- 2000. Strategic Management Journal, v. 25, n. 10, p. 981-1004, 2004.

ROUSE, M.; DAELLENBACH, U. More thinking on research methods for the resourcebased perspective. Strategic Management Journal, v. 23, n. 10, p. 963-967, 2002.

RUMELT, M. How much does industry matter. Strategic Management Journal, v. 12, p. 167-185, 1991.

RUMELT, R. Towards a strategic theory of the firm. In: LAMB, R. (Ed.). Competitive strategic management. New Jersey, NJ: Englewood Cliffs, 1984.

SAPIENZA, H.; AUTIO, E.; GEORGE, G.; ZAHRA, S. A capabilities perspective on the effects of early internationalization on firm survival and growth. Academy of Management Review, v. 31, p. 914-933, 2006.

SHARMA, V.; ERRAMILLI, M. Resource-based explanation of entry mode choice. Journal of Marketing Theory \& Practice, v. 12, n. 1, p. 1-18, 2004.

SINKOVICS, R.; PENZ, E. Social distance between residents and international tourists: Implications for international business. International Business Review, v. 18, n. 5, p. 457 469, 2009.

TAHAI, A.; MEYER, M. A revealed preference study of management journals' direct influences. Strategic Management Journal, v. 20, n. 3, p. 279-296, 1999. 
TALLMAN, S. Strategic management models and resource-based strategies among MNEs in a host market. Strategic Management Journal, v. 12, p. 69-82, 1991.

TALLMAN, S.; FLADMOE-LINDQUIST, K. Internationalization, globalization, and capability-based strategy. California Management Review, v. 45, n. 1, p. 116-135, 2002.

TALLMAN, S.; LI, J. Effects of international diversity and product diversity on the performance of multinational firms. Academy of Management Journal, v. 39, n. 1, p. 179196, 1996.

TEECE, D.; PISANO, G.; SHUEN, A. Dynamic capabilities and strategic management. Strategic Management Journal, v. 18, p. 509-533, 1997.

UHLENBRUCK, K.; DE CASTRO, J. Foreign acquisitions in Central and Eastern Europe: Outcomes of privatization in transitional economies. Academy of Management Journal, v. 43, n. 3, p. 381-402, 2000.

VAPOLA, T.; PAUKKU, M.; GABRIELSSON, M. Portfolio management of strategic alliances: an international business perspective. International Business Review, v. 19, n. 3, p. 247-260, 2010.

VERMEULEN, F.; BARKEMA, H. Learning through acquisitions. Academy of Management Journal, v. 44, p. 457-476, 2001.

WERNERFELT, B. A resource based view of the firm. Strategic Management Journal, v. 5, p. 171-180, 1984.

The resource-based view of the firm: ten years after. Strategic Management Journal, v. 16, p.171-174, 1995.

WHITE, D.; MCCAIN, K. Visualizing a discipline: An author co-citation analysis of information science, 1972-1995. Journal of the American Society for Information Science, v. 49, p. 327-355, 1998.

WHITE, H.; GRIFFITH, B. Author co-citation: A literature measure of intellectual structure. Journal of the American Society for Information Science, v. 32, p. 163-171, 1981.

WILLIAMSON, O. Markets and hierarchies, analysis and antitrust implications: A study in the economics of internal organization. New York, NY: Free Press, 1975.

\section{APPENDIX - MAJOR THEMES: GROUPING OF KEYWORDS}

\begin{tabular}{|l|l|}
\hline $\begin{array}{l}\text { Capabilities, knowledge, } \\
\text { resource-based view } \\
(23)\end{array}$ & $\begin{array}{l}\text { resource-based view; learning; resource-based theory; knowledge; capabilities and } \\
\text { capability development; capabilities view; tacit knowledge; capabilities; firm capabilities; } \\
\text { firm competencies; dynamic capabilities; co-evolution; knowledge transfer; innovation } \\
\text { and capabilities; complementary resources. }\end{array}$ \\
\hline $\begin{array}{l}\text { Internationalization, entry } \\
\text { modes and strategic } \\
\text { advantage (24) }\end{array}$ & $\begin{array}{l}\text { internationalization; foreign market entry; international acquisitions; new ventures; } \\
\text { licensing rights; mode dynamics; mode of entry; born global firms; exports; exporting; } \\
\text { early adopters of internationalization; export behaviours; early internationalization; entry } \\
\text { mode choice; international growth; international joint venture; international exchange } \\
\text { relationships; joint venture sell-off; international venturing. }\end{array}$ \\
\hline $\begin{array}{l}\text { Environmental, geography, } \\
\text { clusters and regional (16) }\end{array}$ & $\begin{array}{l}\text { China; emerging markets; Central and Eastern Europe; Location; localization success; } \\
\text { least developed countries; liability of foreignness; market orientation; Stephen Hymer; }\end{array}$ \\
\hline
\end{tabular}




\begin{tabular}{|c|c|}
\hline & $\begin{array}{l}\text { business and society; cost of doing business abroad; environment; comparative; Hong } \\
\text { Kong; India; transitional economies. }\end{array}$ \\
\hline $\begin{array}{l}\text { Top management team, } \\
\text { human resource } \\
\text { management }(7)\end{array}$ & $\begin{array}{l}\text { Management; perception of top management; human resource management; strategic } \\
\text { HRM; global talent. }\end{array}$ \\
\hline $\begin{array}{l}\text { Multinational enterprise, } \\
\text { subsidiaries (14) }\end{array}$ & $\begin{array}{l}\text { multinational enterprises; multinational corporations; multinationality; multinational } \\
\text { enterprise; multinational corporation; multinationals; MNEs; MNE-host country } \\
\text { relations; emerging-market MNEs; Subsidiaries. }\end{array}$ \\
\hline Institutional theory (11) & $\begin{array}{l}\text { Institutions; institutional theory; institutional environment; markets and institutions; } \\
\text { institutional capital; institutional context. }\end{array}$ \\
\hline $\begin{array}{l}\text { Global, international, } \\
\text { multinational strategies } \\
\text { (12) }\end{array}$ & $\begin{array}{l}\text { strategic change; corporate social responsibility; globalization; corporate social } \\
\text { irresponsibility; international expansion; international business competence; international } \\
\text { performance; international strategy; competitive advantages; competitive disadvantage; } \\
\text { competitive advantage; competitive strategies of local emerging-market firms. }\end{array}$ \\
\hline Diversification (3) & international diversification; regional diversification. \\
\hline Culture (8) & $\begin{array}{l}\text { Culture; Chinese management; Stratification; GLOBE; cultural distance; domestic } \\
\text { mindsets; comparative thinking. }\end{array}$ \\
\hline $\begin{array}{l}\text { Methodologies, theories } \\
\text { and research issues (6) }\end{array}$ & $\begin{array}{l}\text { multidimensional scaling; case theoretic approaches; survey; time series cross-sectional } \\
\text { analysis; evaluation of current theories; empirical. }\end{array}$ \\
\hline $\begin{array}{l}\text { Foreign direct investment } \\
\text { (5) }\end{array}$ & FDI; outward FDI; foreign investors; cross-border investment. \\
\hline Transaction cost theory (3) & transaction cost economics; transaction cost theory. \\
\hline Growth models (3) & prior conditions; resource dependency; evolutionary economics. \\
\hline Entrepreneurship (8) & $\begin{array}{l}\text { returning entrepreneurs; family firms; corporate entrepreneurship; entrepreneurship } \\
\text { business strategy; entrepreneurship; entrepreneurial firms; entrepreneurship; international } \\
\text { new ventures. }\end{array}$ \\
\hline $\begin{array}{l}\text { Networks, alliances and } \\
\text { cooperative arrangements } \\
(6)\end{array}$ & Networks; managerial ties; path; relational norms; cooperativeness. \\
\hline Performance (17) & $\begin{array}{l}\text { Performance; firm performance; value creation; stock market valuation; perceived } \\
\text { performance; initial public offerings; client-perceived value. }\end{array}$ \\
\hline $\begin{array}{l}\text { R\&D, technology, } \\
\text { innovation (10) }\end{array}$ & $\begin{array}{l}\text { Innovation; monopoly rents; management of technology; value capture; product } \\
\text { development; innovation and R\&D; intellectual property; innovativeness. }\end{array}$ \\
\hline Organization structure (5) & Governance; ownership/control structures; ownership; control. \\
\hline Functional strategies (16) & $\begin{array}{l}\text { channel governance; outsourcing; offshoring; modularization; modular production; } \\
\text { marketing; supply chain management; service; services; business processes; export } \\
\text { marketing; global sourcing; distribution channels; international marketing; international } \\
\text { services marketing. }\end{array}$ \\
\hline $\begin{array}{l}\text { Small and medium } \\
\text { enterprise ( } 3 \text { ) }\end{array}$ & SMEs; small and medium-sized enterprises (SMEs); small and medium enterprise. \\
\hline Industry analysis (3) & echnology (IT); industry factors. \\
\hline
\end{tabular}

Note: in parentheses the frequency with which these major keywords appear in the articles citing Barney (1991).

Source: data collected from ISI - Web of Knowledge. Authors computations using bibexcel. 